ISSN 1678-3921

Journal homepage: www.embrapa.br/pab

For manuscript submission and journal contents, access: www.scielo.br/pab

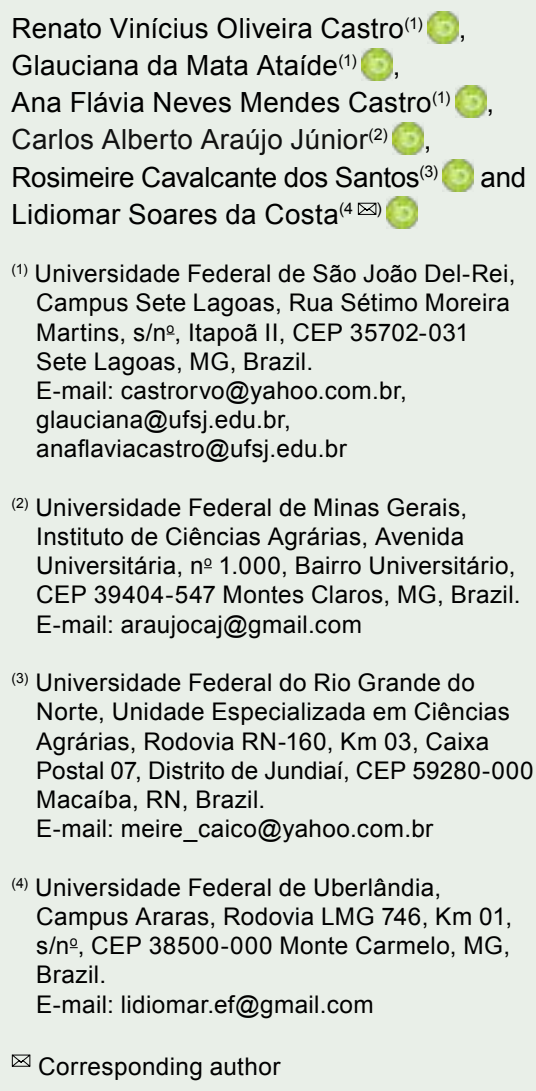

(2) Universidade Federal de Minas Gerais, Instituto de Ciências Agrárias, Avenida Universitária, ํㅡ 1.000, Bairro Universitário, CEP 39404-547 Montes Claros, MG, Brazil. E-mail: araujocaj@gmail.com

(3) Universidade Federal do Rio Grande do Norte, Unidade Especializada em Ciências Agrárias, Rodovia RN-160, Km 03, Caixa Postal 07, Distrito de Jundiaí, CEP 59280-000 Macaíba, RN, Brazil.

E-mail: meire_caico@yahoo.com.br

(4) Universidade Federal de Uberlândia, Campus Araras, Rodovia LMG 746, Km 01, $\mathrm{s} / \mathrm{n}^{\circ}$, CEP 38500-000 Monte Carmelo, MG, Brazil.

E-mail: lidiomar.ef@gmail.com

$\bowtie$ Corresponding author

Received

May 9, 2018

Accepted

January 23, 2019

How to cite

CASTRO, R.V.O.; ATAÍDE, G. da M.; CASTRO, A.F.N.M.; ARAÚJO JÚNIOR, C.A.; SANTOS, R.C. dos; COSTA, L.S. da. Feasibility of wood production according to productivity class and rotation criteria. Pesquisa Agropecuária Brasileira, v.54, e00778, 2019. DOI: https://doi. org/10.1590/S1678-3921.pab2019.v54.00778.

\section{Feasibility of wood production according to productivity class and rotation criteria}

\begin{abstract}
The objective of this work was to evaluate the effect of forest rotation on the technical and economic feasibility of eucalyptus wood production for charcoal, in different productivity classes. Data came from Eucalyptus stands whose area was stratified into three classes of productivity: high, medium, and low. To each class, a different criterion of forest rotation was applied, as follows: age of maximum productivity, economic rotation age, single harvest age, and no technical parameter. Analyses of economic feasibility and production were performed for a 21-year planning horizon. For rotation without a technical parameter, a simulation by the Monte Carlo method was performed. For all rotation criteria, feasibility was observed for high- and medium-productivity classes, and unfeasibility for the low-productivity class. For rotation without a technical parameter, there is no chance for the project to be unfeasible. Wood production viability for charcoal under the studied conditions depends on the productivity class, for any rotation criterion adopted. Rotation criterion influences profitability, whose definition, according to productivity class, contributes to forest production maximization and to the economic return of the project, under the studied conditions.
\end{abstract}

Index terms: forest economics, forest planning, harvest age.

\section{Viabilidade da produção de madeira em função da classe de produtividade e do critério de rotação}

Resumo - O objetivo deste trabalho foi avaliar o efeito da rotação florestal sobre a viabilidade técnica e econômica da produção de madeira de eucalipto para carvão, em diferentes classes de produtividade. Utilizaram-se dados de povoamentos de Eucalyptus cuja área foi estratificada em três classes de produtividade: alta, média e baixa. A cada classe, aplicaram-se diferentes critérios de rotação florestal, conforme: idade de máxima produtividade, idade econômica de corte, única idade de corte e rotação sem parâmetro técnico. Realizaram-se análises de viabilidade econômica e de produção para o horizonte de planejamento de 21 anos. Para a rotação sem parâmetro técnico, realizou-se uma simulação pelo método de Monte Carlo. Para todos os critérios de rotação, observou-se viabilidade para as classes de alta e média produtividade, e inviabilidade para a classe de baixa produtividade. Para a rotação sem parâmetro técnico, não há chance de o projeto ser inviável. A viabilidade da produção de madeira para carvão nas condições estudadas depende da capacidade produtiva do local, para qualquer critério de rotação adotado. O critério de rotação influencia a rentabilidade, cuja definição, em razão da capacidade produtiva do local, contribui para a maximização da produção e para o retorno econômico do projeto florestal nas condições estudadas.

Termos para indexação: economia florestal, planejamento florestal, idade de corte. 


\section{Introduction}

In 2016, Brazil had a total of 7.84 million hectares of planted forests, out of which 5.80 million were Eucalyptus spp. (IBÁ, 2017). One of the biggest advantages of eucalyptus plantations is its high-growth rate, known to be the highest in the world among the hardwood forests (Stape et al., 2010; Myburg et al., 2014). This high-growth rate, combined with a correct planning, allows of the efficient supply of the demand for wood for different purposes, such as cellulose and paper, charcoal, energy, among others, since the settlements may have smaller rotation periods.

In the process of forest planning, one of the main factors is the correct definition of rotation age, as the productive structure depends on the wood flow, which is planned based on the age previously established for harvest (Nautiyal, 2011). The forest stands rotation can be influenced by several factors, which may be technical and economical. Among the technical factors the productive capacity of the site can be highlighted, and can be defined as the potential to produce wood or other type of product, under the existing environmental conditions and silvicultural techniques employed, in a given area, for a particular species or clone (Leite et al., 2011). Forest area classification as to its productivity potential is of great importance for the stratification of regions, which allows of the decision making on the type of forest management possible, according to the productive capacity of these areas (Bila et al., 2012).

Many studies have been published involving the economic analyses (Cordeiro et al., 2014; Virgens et al., 2016; Timofeiczyk Junior et al., 2017), effects and classifications of productive capacity (Retslaff et al., 2015; Castro et al., 2016; Silva et al., 2018), and rotation of forest stands (Rodriguez et al., 1997; Resende et al., 2004). However, there are no studies evaluating the profitability and economic feasibility of eucalyptus forest projects for charcoal production, taking into account the variation of forest stands rotation, and economic feasibility.

The objective of this work was to evaluate the forest rotation effect on the technical and economic feasibility of eucalyptus wood production, in different classes of productivity, destined for charcoal making.

\section{Materials and Methods}

Data used in the present work refer to nonthinned stands of clones and hybrids of Eucalyptus spp., belonging to a forestry company located in the northwest of Minas Gerais state $\left(17^{\circ} 36^{\prime} \mathrm{S}\right.$ and $\left.46^{\circ} 42^{\prime} \mathrm{W}\right)$, conducted for charcoal production in a high-forest system. The climate of the region, according to the Köppen-Geiger's classification, is Aw-tropical climate with dry winters. The average annual temperature is $22.6^{\circ} \mathrm{C}$, and annual average precipitation is $1.450 \mathrm{~mm}$.

The production area had 4,052 hectares, with stands established in $3.0 \times 2.0 \mathrm{~m}$ spacing, and it was initially stratified in three productivity classes: high, medium, and low. The high-productivity class (HP) was in a 1,398 ha area, the medium one (MP) in a 1,230 ha area, and the low-productivity class (LP) in a 1,424 ha area. The volume growth curves in each productivity class were described by the logistic model (Figure 1).

The forest rotation criteria were defined by the age of maximum productivity (AMP), that is, the forest rotations set by the ages of maximum productivity were 51 (HP), 56 (MP), and 61 (LP) months; the economic rotation age (ERA), in which forest rotation is defined by the economic harvest age -60 months for HP, and 72 months for MP and LP classes; single harvest age (SHA), which is performed by cutting the forest at 84 months, for all productivity classes; and rotation with no technical parameter (NTP), which is the rotation without technical or economic criteria. The forest is harvest in the range of age between 51 to 102 months.

The rotation set by AMP, in the different productivity classes, is obtained when the mean annual increment (MAI) is maximum and equal to the current annual increment (CAI) (Campos \& Leite, 2017). The net present value of an infinite series is used for the definition of the ERA, considering an interest rate of $8 \%$. The SHA alternative is established as an average age of 84 months, regardless of the productivity class.

NTP was established based on the frequency of distribution of rotation ages, observed in the company over the last 10 years, in the conduction of the stands. This variation range is often a consequence of the company's logistical factors, due to the need to cut newer or older forests than that in the established age because of the distance of the processing units at some time of the year, such as in the rainy season, or because of the availability of labor close to certain sites. 
Operations costs considered in the accomplishment of the present work were provided by technical managers for the implantation and conduction of the stands (Table 1). The interest rate of $8 \%$ per year was considered, as well as the cost of harvesting and extraction at $\mathrm{R} \$ 19.00 \mathrm{~m}^{-3}$, and the price of wood, cut, and stack at $\mathrm{R} \$ 60.00 \mathrm{~m}^{-3}$. The land factor cost was considered by the method of interest on the value of the land, as, according to Silva et al. (2008), it provides more consistent results with market values.

For the analysis of economic and technical feasibility of wood production a 21-year planning horizon was considered. The economic feasibility evaluation under the four alternatives of rotation forest was performed using two methods: net present value (NPV) and internal rate of return (IRR) (Silva \& Fontes, 2005; Rezende \& Oliveira, 2008). The IRR is considered an average rate of project growth, which is considered feasible if its value is greater than or equal to the rate of return on capital, usually known as the minimum acceptable rate of return (rate used in financial investments, such as savings etc.). In the presents work, the minimum acceptable rate of return (MARR) was considered as 8.0\% (Silva et al., 2013).

In the technical feasibility analysis, the wood volume obtained from each rotation criterion, during the determined planning horizon (21 years), was calculated from the respective production equations for the productive capacity classes.

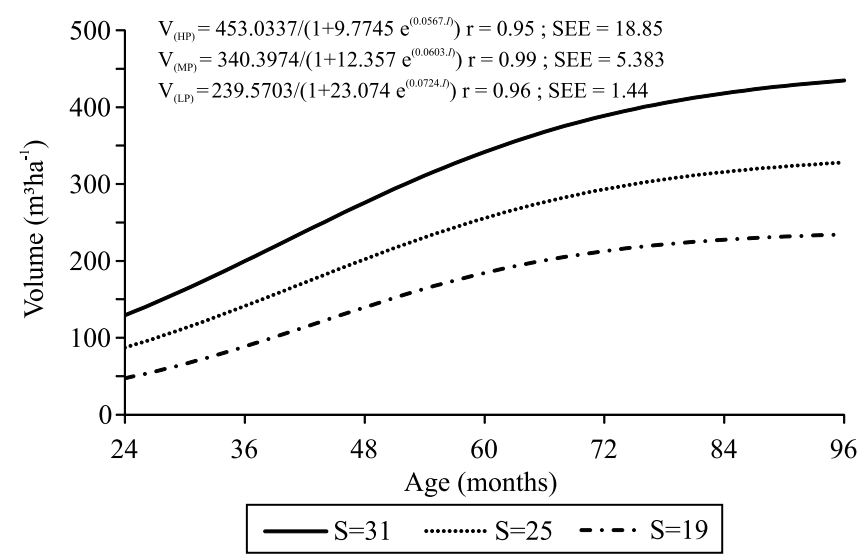

Figure 1. Wood production curves of Eucalyptus spp. stands, in areas of high- (HP), medium- (MP), and lowproductive capacity (LP), in the northwest region of the state of Minas Gerais, Brazil. V, volume $\left(\mathrm{m}^{3}\right)$; I, age (months); $r$, correlation coefficient; and SEE, standard error of the estimate.
The AMP, ERA, and SHA criteria are deterministic in nature, which presuppose certainty on the values of NPV, IRR, and production obtained at established harvest ages, since these ages were fixed in each productivity class. The SPT criterion, however, is classified as probabilistic because it covers a wide range of ages. Thus, Monte Carlo simulation was performed, using the software@RISK (Ithaca, NY, USA),

Table 1. Data of the implementation and maintenance costs, used in the economic viability analysis of wood production for charcoal from Eucalyptus spp. in the northwest of Minas Gerais.

\begin{tabular}{|c|c|c|}
\hline Year & Activity/input & $\begin{array}{c}\text { Cost } \\
\left(\mathrm{R} \$ h^{-1}\right)\end{array}$ \\
\hline 0 & Ant control & 110.00 \\
\hline 0 & Mechanical mowing in total area & 50.00 \\
\hline 0 & Limestone application in total area & 35.00 \\
\hline 0 & Herbicide application in total area & 35.00 \\
\hline 0 & Harrowing on the subsoiling line & 45.00 \\
\hline 0 & Subsoiling with phosphating & 150.00 \\
\hline 0 & Planting & 90.00 \\
\hline 0 & Replanting & 30.00 \\
\hline 0 & Manual application of fertilizer (NPK) & 80.00 \\
\hline 0 & Chemical control of intra-row weed & 100.00 \\
\hline 0 & Seedlings transportation to the field & 15.00 \\
\hline 0 & Intra-row sprout thinning with hoe & 90.00 \\
\hline 0 & Inter-row mechanical mowing & 45.00 \\
\hline 0 & Inter-row herbicide application & 45.00 \\
\hline 0 & Intra-row herbicide application (costal sprayer) & 100.00 \\
\hline 0 & Maintenance of seedling deposit & 10.00 \\
\hline 0 & Top-dressing fertilization (90 days, manual) & 80.00 \\
\hline 0 & Irrigation $(1 \mathrm{x})$ & 120.00 \\
\hline 0 & NPK fertilizer 06-30-06 + micros & 150.00 \\
\hline 0 & Reactive phosphate & 301.0 \\
\hline 0 & Termiticide & 35.00 \\
\hline 0 & Formicidal bait & 65.00 \\
\hline 0 & Powdered formicide & 3.00 \\
\hline 0 & Glyphosate herbicide & 72.00 \\
\hline 0 & Pre-emergence herbicide & 50.00 \\
\hline 0 & Soil conditioner (gel) & 30.00 \\
\hline 0 & NPK fertilizer $20-00-20+$ micros & 216.00 \\
\hline 0 & Clonal seedlings & 437.50 \\
\hline 1 & $\begin{array}{l}\text { Herbicide }+ \text { fertilizer }+ \text { formicide }+ \text { labor }+ \\
\text { firebreaks conservation }\end{array}$ & 550.00 \\
\hline 2 & $\begin{array}{l}\text { Herbicide }+ \text { fertilizer }+ \text { formicide }+ \text { labor }+ \\
\text { firebreaks conservation }\end{array}$ & 350.00 \\
\hline 3 to 8 & Formicide + labor + firebreaks conservation & 100.00 \\
\hline 1 to $n$ & Land & 224.00 \\
\hline 1 to $n$ & Administration & 80.00 \\
\hline 0 and $\mathrm{n}$ & Licenses, rates & 100.00 \\
\hline $\mathrm{n}$ & Pre-harvest mowing & 90.00 \\
\hline
\end{tabular}

$\mathrm{n}$ : harvest age. 
to evaluate this scenario. Two thousand interactions were simulated, by alternating the rotation age in each productivity class according to the real frequency of harvest ages, which was the same for the three productivity classes.

The Monte Carlo method for the simulation was applied in the following sequence: the probability distribution of the harvest ages (rotation) was identified; the value of the harvest age was selected at random from its probability distribution; the value of the dependent variable of interest (NPV, IRR, and production) was calculated; the process was repeated until the complete frequency distribution of the dependent variables was obtained.

\section{Results and discussion}

In the analyzed harvest ages, the alternative showing the lower-economic viability for wood production was the one that adopted the harvest without a defined technical or economic parameter, while the technical viability was reduced when a single harvest age was adopted, in the three productivity classes (Table 2).

Rodriguez et al. (1997) argue that a harvest age defined regardless of economic issues - as the values of the products obtained with the forest harvest, the opportunity cost of the capital asset, and the time of land occupation in each forest rotation - may compromise the feasibility of a forestry project. However, Resende et al. (2004) suggest that choosing the best cycle cannot be made without considering technical issues, among which these authors include yields obtained, wood demand, and operational characteristics of the area.

The economic criteria NPV and IRR indicated feasibility for high- and medium-productivity classes, and unfeasibility for the low-productivity class, for all harvest ages.

Forestry projects implemented in areas classified as low-productivity would only be viable under interest rates lower than those of the IRR obtained for the used harvesting criteria, which usually does not happen in the forestry sector. An alternative to be considered for these areas is the diversification of wood products, and the uses that provide greater economic return. The productive capacity of the site, by directly affecting the growth and production of forest stands, acts as an intensifier of economic results, with effects on both the optimal economic harvest age and the profitability.
The stands stratification by their productive capacity is important for harvest forest planning (Oliveira et al., 2008), given that in sites with low-productive capacity, the tendency is that the growth rates of forest species are smaller. In other words, more time are required to reach the volumetric production potential as to the technical harvest age, which would result in low profitability of the project.

For the high-productivity class, the NPV and IRR values were higher than $\mathrm{R} \$ 5,500.00 \mathrm{ha}^{-1}$ and $16.0 \%$, respectively, among the four rotation age alternatives, showing the high viability of these projects. The ERA criterion showed itself more advantageous among the proposed alternatives. Therefore, considering a high-productivity site, the decision to cut the forest in different ages of EHA could result in a reduction of profitability between 23.2 and $31.6 \%$ by the NPV criterion, and between 21.8 and $26.8 \%$ by the IRR criterion.

Spathelf \& Seling (2000) studied the economic effects of different thinning programs of Pinus elliottii stands, and observed that the IRR decreased as the rotation age increased. However, for the present work, this situation could not apply completely, and both IRR

Table 2. Economic indicators, net present value (NPV), internal rate of return (IRR), and wood production of Eucalyptus spp. stands, for different productivity classes and forest rotation criteria, in the northwest of the state of Minas Gerais, Brazil.

\begin{tabular}{lcccc}
\hline Indicators & Rotation & \multicolumn{3}{c}{ Productivity class } \\
\cline { 3 - 5 } criterion $^{(1)}$ & HP & MP & LP \\
\cline { 3 - 5 } & AMP & $5,603.0$ & $1,825.0$ & $-1,853.0$ \\
NPV & ERA & $8,165.0$ & $2,648.0$ & $-1,431.0$ \\
$\left(\mathrm{R} \$\right.$ ha $\left.^{-1}\right)$ & SHA & $6,272.0$ & $2,082.0$ & $-1,484.0$ \\
& NTP & $5,584.0$ & $1,449.0$ & $-2,106.0$ \\
\hline & AMP & 17.2 & 11.8 & 2.8 \\
IRR & ERA & 22.0 & 12.9 & 4.6 \\
$(\%)$ & SHA & 17.0 & 11.5 & 5.1 \\
& NTP & 16.1 & 10.5 & 3.6 \\
\hline & AMP & $1,451.0$ & $1,061.0$ & 760.0 \\
Wood $_{\text {production }}$ & ERA & $1,443.0$ & $1,021.0$ & 727.0 \\
$\left(\mathrm{~m}^{3} \text { ha }^{-1}\right)^{(2)}$ & SHA & $1,254.0$ & 947.0 & 683.0 \\
& NTP & $1,300.0$ & 975.0 & 697.0 \\
\hline
\end{tabular}

(1)AMP, age of maximum productivity; ERA, economic rotation age; SHA, single harvest age; and NTP, no technical parameter. ${ }^{(2)}$ For the planning horizon. 
and NPV were highly influenced by the productive capacity of the site, which in turn influenced the forest rotation age.

Among the criteria of rotation, ERA and AMP are those defined in more detail; it should be noted that AMP shows economic indicators very similar to those of the SHA and NTP criteria. In the high- and medium -productivity classes, all forest rotation options are feasible; however, considering the production of wood for own consumption, as in the cases of companies producing cellulose and charcoal, AMP rotation is the best option, as the production reaches rates from 8.1 to $13.6 \%$, higher than the SHA and NTP criteria.

The recommendation of a single harvest age for species of the genus Eucalyptus disregards the rotation, the type of species growth, the use of different interest rates, among others (Rodriguez et al., 1997). Such generalization impairs the productivity gains of the forest, since the species and clones currently planted have high-physiological and nutritional efficiency, which results in higher rates of stand growth. Growth tends to stabilize earlier, with a consequent lowertechnical harvesting age, which justifies the harvest anticipation (Ferreira et al., 2017; Gonçalves et al., 2017).

The global economic and technical indicators, considering the entire forest, without stratification by productivity class, indicate feasibility for wood production under the analyzed conditions for all the alternatives of rotation age (Table 3 ).

The lowest economic return was obtained by the NTP alternative, whose NPV was $47.9 \%$ lower than

Table 3. Global indicators, net present value (NPV), internal rate of return (IRR), and wood production of Eucalyptus spp. stands, for different productivity classes and forest rotation criteria, in the northwest of the state of Minas Gerais, Brazil.

\begin{tabular}{lccc}
\hline $\begin{array}{l}\text { Rotation } \\
\text { criterion }^{(1)}\end{array}$ & $\begin{array}{c}\text { NPV } \\
\left(\mathrm{R} \$ \mathrm{ha}^{-1}\right)\end{array}$ & $\begin{array}{c}\text { IRR } \\
(\%)\end{array}$ & $\begin{array}{c}\text { Wood production } \\
(2)\end{array}$ \\
\hline AMP & $1,836.0$ & 10.5 & $1,090.0$ \\
ERA & $3,118.0$ & 13.1 & $1,063.0$ \\
SHA & $2,274.0$ & 11.2 & 960.0 \\
NTP & $1,626.0$ & 10.0 & 989.0 \\
\hline
\end{tabular}

(1) AMP, age of maximum productivity; ERA, economic rotation age; SHA, single harvest age; and NTP, no technical parameter. ${ }^{(2)}$ For the planning horizon. that option with the highest-economic return. It can be observed that this alternative offers the biggest investment risk, showing lower IRR. However, the financial return obtained by the ERA was dependent on the flow of costs and revenues adopted by the company, which are variables for the various regions of the country, as well as interest rates adopted (Vitale $\&$ Miranda, 2010; Folmann et al., 2014; Chichorro et al., 2017).

This result also indicates that the definition of the criterion of forest rotation, consistent with the planning for the destination of the produced wood, contributes to the fact that the activity is financially and technically more advantageous. Forest planning, which encompasses, among other things, the implantation and age of forest rotation, is a process in which the planner needs to know about the many variables, constraints, and assumptions that range from forest formation to timber delivery, so that wood costs suit with reality.

The AMP criterion showed a global production of up to $11.9 \%$, higher than that of the other rotation criteria, but still with a lower NPV and IRR than those of the ERA and SHA options. This was due to the rotation that was lower for the AMP alternative, in comparison to that used in other options. This results in higher costs of deployment throughout the analyzed period to allow of a continuous flow of wood, and such a situation corroborates the report of Guerra-Bugueño et al. (2014), who performed an economic evaluation of Eucalyptus globulus plantations, and observed that the cost of deployment could reduce profitability.

The practice of forest rotation without technical parameters led to the harvesting of forest stands at higher ages more frequently than those with maximum productivity and optimum economic situation (Figure 2). Therefore, for this alternative, a lower viability was observed.

In the analysis of the minimum values obtained for the economic indicators, the chance that a global investment be economically unviable was observed as null, and NPV and IRR were observed as very close to the normal distribution, which means that about 50\% probability shows a result below average, as well as $50 \%$ of it, above the average (Figure 3). Timofeiczyk Junior et al. (2017) observed a similar behavior for these economic indicators, in a risk assessment for Pinus taeda stands. These authors also mention that 
the use of the Monte Carlo method is more secure for projects and investment recommendations.

For the production obtained by the NTP alternative, the distribution of probability shows that volumetric increments smaller than $1000 \mathrm{~m}^{3} \mathrm{ha}^{-1}$ have at least $75 \%$ chance of occurrence. This production is lower than the most advantageous criteria, ERA and AMP; in addition, the NTP has a longer rotation period. Rotation age of forests can be greatly influenced by the demand for larger trees, which justifies the adoption of higherrotation ages (Castro et al., 2011; Weimann et al., 2017). But, when it comes to the wood production for charcoal, the tree individual volume is not considered.

The economic rotation is cited as the most convenient, since it considers interest rates, production costs, and tree dimensions (Silva et al., 2012). However, Nautiyal (2011) states that a rigid criterion should not be applied in the definition of harvest age, in order to preserve the interests of the company. In case of any changes in economic conditions, or the company's objectives, the criteria used should follow such changes. The present work corroborates such statement because it shows that more than one option is feasible. For situations that prioritizes the maximum productivity, the production can be destined to self-supply; and for situations in which maximum profitability is sought, wood is produced to be marketed.

Not always, will the optimal rotation age (AMP or ERA) be applied for all the management units due to restrictions imposed by the regulation model,

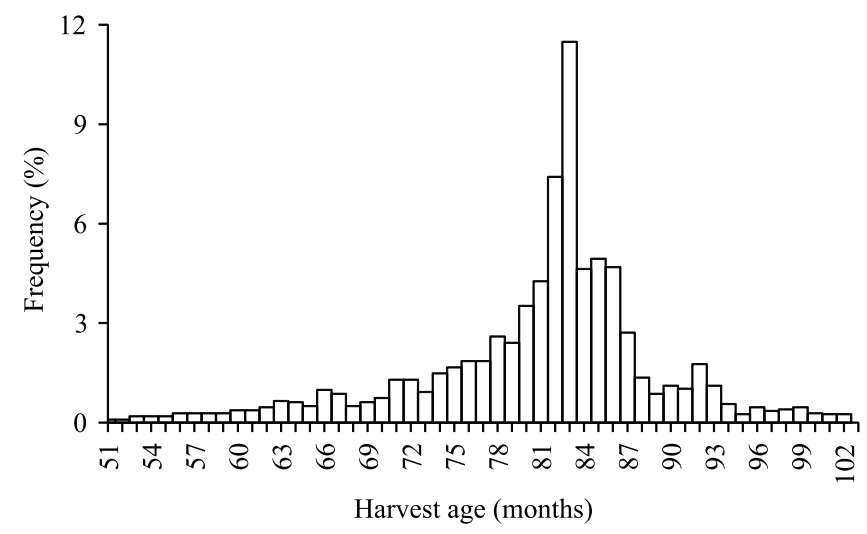

Figure 2. Age frequency distribution at which Eucalyptus spp. stands were harvested under no technical parameter (NTP) in a 10 -year period. or market oscillations. However, it can be affirmed that the establishment of the harvest on the basis of a concise and appropriate forest planning is essential for maximization of results, while rotations without preset parameters can affect the economic sustainability of the project.
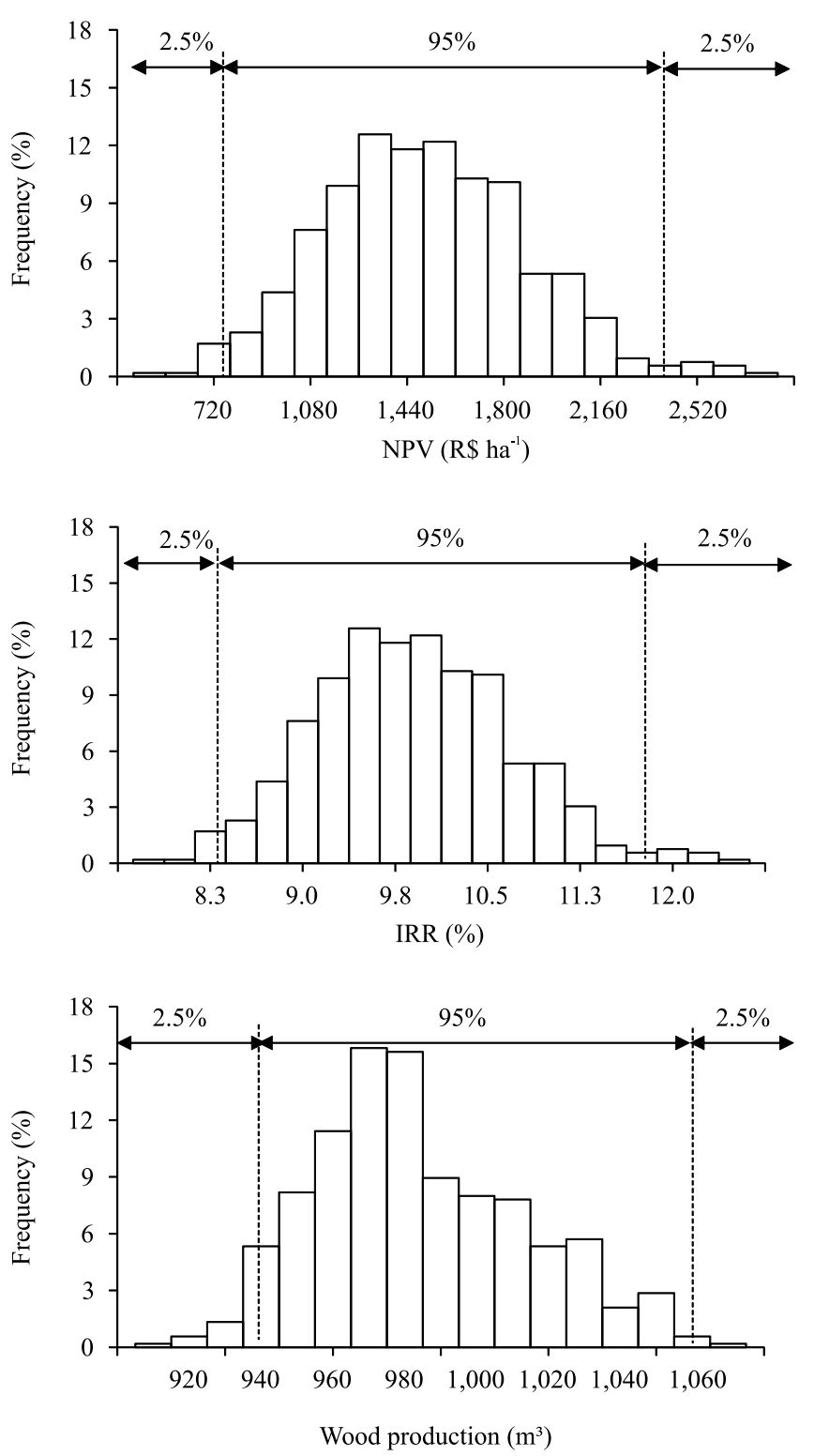

Figure 3. Probability distribution of global economic indicators, net present value (NPV), internal rate of return (IRR), and wood production of Eucalyptus spp. stands that were harvested under no technical parameter (NTP), in the northwest of the state of Minas Gerais, Brazil. 


\section{Conclusions}

1. The viability of wood production for charcoal, in the studied conditions, depends on the productivity class for any rotation criterion adopted.

2. The rotation criterion influences profitability, and the definition of profitability according to the productivity class, contributes to the forest production maximization, and to the economic return of the project.

\section{References}

BILA, J.M.; SANQUETTA, C.R.; MACHADO, S. do A. Classificação de sítios com base em fatores edáficos para Pinus caribaea var. hondurensis na região de Prata, Minas Gerais. Floresta, v.42, p.465-474, 2012. DOI: https://doi.org/10.5380/ rf.v42i3.19014.

CAMPOS, J.C.C.; LEITE, H.G. Mensuração florestal: perguntas e respostas. 5.ed. atual. e ampl. Viçosa: UFV, 2017. 636p.

CASTRO, R.V.O.; ARAÚJO, R.A.A.; LEITE, H.G.; CASTRO, A.F.N.M.; SILVA, A.; PEREIRA, R.S.; LEAL, F.A. Modelagem do crescimento e da produção de povoamentos de Eucalyptus em nível de distribuição diamétrica utilizando índice de local. Revista Árvore, v.40, p.107-116, 2016. DOI: https://doi.org/10.1590/010067622016000100012.

CASTRO, R.V.O.; LEITE, H.G.; NOGUEIRA, G.S.; SOARES, C.P.B.; ARAÚJO JÚNIOR, C.A.; CASTRO, A.F.N.M.; CRUZ, J.P. da; SANTOS, F.L. dos; SOUZA, C.C. Avaliação econômica de um povoamento de eucalipto desbastado e destinado a multiprodutos da madeira. Scientia Forestalis, v.39, p.351-357, 2011.

CHICHORRO, J.F.; SILVA, A.L.P. da; ANDRADE, W.S. de P.; HEGEDUS, C.E.N.; KUBOYAMA, F.A.Q. Custos e índices econômicos de povoamentos de eucalipto do Programa Produtor Florestal no Espírito Santo. Pesquisa Florestal Brasileira, v.37, p.447-456, 2017. DOI: https://doi.org/10.4336/2017.pfb.37.92.1232.

CORDEIRO, S.A.; SILVA, M.L. da; OLIVEIRA NETO, S.N. de; OLIVEIRA, T.M. de; NERY, K.C.M. da S. Análise de custos e rendimentos de sistemas agroflorestais na Zona da Mata (MG). Revista Agrogeoambiental, v.6, p.59-70, 2014. DOI: https://doi.org/10.18406/2316-1817v6n22014600.

FERREIRA, D.H.A.A.; LELES, P.S. dos S.; OLIVEIRA NETO, S.N. de; PAULA, T.R.; COUTINHO, R.P.; SILVA, R.L. da. Crescimento e produção de eucalipto na região do Médio Paraíba do Sul, RJ. Floresta e Ambiente, v.24, e00131315, 2017. DOI: https://doi.org/10.1590/2179-8087.131315.

FOLMANN, W.T.; MIRANDA, G. de M.; DIAS, A.N.; MORO, F. de C.; FERNANDEZ, M.L.Q. Viabilidade de projetos florestais em três regimes de manejo na Mesorregião CentroOriental do Paraná. Floresta, v.44, p.153-160, 2014. DOI: https://doi.org/10.5380/rf.v44i1.30096.

GONÇALVES, J.C.; OLIVEIRA, A.D. de; CARVALHO, S. de P.C. e; GOMIDE, L.R. Análise econômica da rotação florestal de povoamentos de eucalipto utilizando a simulação de Monte Carlo. Ciência Florestal, v.27, p.1339-1347, 2017. DOI: https://doi.org/10.5902/1980509830215.

GUERRA-BUGUEÑO, E.; CÉLIS-MOSQUEIRA, F.; MORENO-GARCÍA, N. Efecto de la densidad de plantación en la rentabilidad de plantaciones de Eucalyptus globulus. Revista Chapingo Serie Ciencias Forestales y del Ambiente, v.20, p.2131, 2014. DOI: https://doi.org/10.5154/r.rchscfa.2012.08.051.

IBÁ. Indústria Brasileira de Árvores. Relatório IBÁ 2017. Brasília, 2017. 80p.

LEITE, H.; CASTRO, R.; SILVA, A.; JÚNIOR, C.; BINOTI, D.; CASTRO, A.F.; BINOTI, M. Classificação da capacidade produtiva de povoamentos de eucalipto utilizando diâmetro dominante. Silva Lusitana, v.19, p.181-195, 2011.

MYBURG, A.A.; GRATTAPAGLIA, D.; TUSKAN, G.A.; HELLSTEN, U.; HAYES, R.D.; GRIMWOOD, J.; JENKINS, J.; LINDQUIST, E.; TICE, H.; BAUER, D.; GOODSTEIN, D.M.; DUBCHAK, I.; POLIAKOV, A.; MIZRACHI, E.; KULLAN, A.R.K.; HUSSEY, S.G.; PINARD, D.; VAN DER MERWE, K.; SINGH, P.; VAN JAARSVELD, I.; SILVA-JUNIOR, O.B.; TOGAWA, R.C.; PAPPAS, M.R.; FARIA, D.A.; SANSALONI, C.P.; PETROLI, C.D.; YANG, X.; RANJAN, P.; TSCHAPLINSKI, T.J.; YE, C.-Y.; LI, T.; STERCK, L.; VANNESTE, K.; MURAT, F.; SOLER, M.; SAN CLEMENTE, H.; SAIDI, N.; CASSANWANG, H.; DUNAND, C.; HEFER, C.A.; BORNBERG-BAUER, E.; KERSTING, A.R.; VINING, K.; AMARASINGHE, V.; RANIK, M.; NAITHANI, S.; ELSER, J.; BOYD, A.E.; LISTON, A.; SPATAFORA, J.W.; DHARMWARDHANA, P.; RAJA, R.; SULLIVAN, C.; ROMANEL, E.; ALVES-FERREIRA, M.; KÜlHEIM, C.; FOLEY, W.; CAROCHA, V.; PAIVA, J.; KUDRNA, D.; BROMMONSCHENKEL, S.H.; PASQUALI, G.; BYRNE, M.; RIGAULT, P.; TIBBITS, J.; SPOKEVICIUS, A.; JONES, R.C.; STEANE, D.A.; VAILLANCOURT, R.E.; POTTS, B.M.; JOUBERT, F.; BARRY, K.; PAPPAS JR, G.J.; STRAUSS, S.H.; JAISWAL, P.; GRIMA-PETTENATI, J.; SALSE, J.; VAN DE PEER, Y.; ROKHSAR, D.S.; SCHMUTZ, J. The genome of Eucalyptus grandis. Nature, v.510, p.356-362, 2014. DOI: https://doi.org/10.1038/nature13308.

NAUTIYAL, J.C. Forest economics: principles and applications. Toronto: Natraj, 2011. 580p.

OLIVEIRA, M.L.R. de; LEITE, H.G.; NOGUEIRA, G.S.; GARCIA, S.L.R.; SOUZA, A.L. de. Classificação da capacidade produtiva de povoamentos não desbastados de clones de eucalipto. Pesquisa Agropecuária Brasileira, v.43, p.1559-1567, 2008. DOI: https://doi.org/10.1590/S0100-204X2008001100015.

RESENDE, R.R.; VALE, A.B. do; SOARES, T.S.; SILVA, M.L. da; COUTO, L.; VALE, R.S. do. Emprego de um modelo de crescimento e produção para determinação da rotação em povoamentos de eucalipto. Revista Árvore, v.28, p.219-225, 2004. DOI: https://doi.org/10.1590/S0100-67622004000200008.

RETSLAFF, F.A. de S.; FIGUEIREDO FILHO, A.; DIAS, A.N.; BERNETT, L.G.; FIGURA, M.A. Curvas de sítio e relações hipsométricas para Eucalyptus grandis na região dos Campos Gerais, Paraná. Cerne, v.21, p.219-225, 2015. DOI: https://doi.or g/10.1590/01047760201521021349. 
REZENDE, J.L.P.; OLIVEIRA, A.D. Análise econômica e social de projetos florestais. 2.ed. Viçosa: UFV, 2008. 386p.

RODRIGUEZ, L.C.E.; BUENO, A.R.S.; RODRIGUES, F. Rotações de eucaliptos mais longas: análise volumétrica e econômica. Scientia Forestalis, n.51, p.15-28, 1997.

SILVA, C.S.J. e; OLIVEIRA, A.D. de; REZENDE, J.L.P. de; MELLO, J.M. de; SCOLFORO, J.R.S. Economic feasibility and rotation age for stands of candeia (Eremanthus erythropappus). Cerne, v.18, p.695-706, 2012. DOI: https://doi.org/10.1590/S010477602012000400020 .

SILVA, G.C.C.; CALEGARIO, N.; SILVA, A.A.L. da; CRUZ, J.P. da; LEITE, H.G. Site index curves in thinned and non-thinned eucalyptus stands. Forest Ecology and Management, v.408, p.36-44, 2018. DOI: https://doi.org/10.1016/j.foreco.2017.10.036.

SILVA, M.L. da; FONTES, A.A. Discussão sobre os critérios de avaliação econômica: Valor Presente Líquido (VPL), Valor Anual Equivalente (VAE) e Valor Esperado da Terra (VET). Revista Árvore, v.29, p.931-936, 2005. DOI: https://doi.org/10.1590/ S0100-67622005000600012.

SILVA, M.L.; JACOVINE, L.A.G.; VALVERDE, S.R. Economia florestal. Viçosa: UFV, 2013. 178p.

SILVA, M.L.; RESENDE, J.L.P. de; LIMA JÚNIOR, V.B.; CORDEIRO, S.A.; COELHO JÚNIOR, L.M. Métodos do cálculo de custo da terra na atividade florestal. Cerne, v.14, p.75-81, 2008.

SPATHELF, P.; SELING, I. Efeitos econômicos de diferentes programas de desbaste em povoamentos de
Pinus elliottii. Ciência Florestal, v.10, p.21-44, 2000. DOI: https://doi.org/10.5902/19805098393.

STAPE, J.L.; BINKLEY, D.; RYAN, M.G.; FONSECA, S.; LOOS, R.A.; TAKAHASHI, E.N.; SILVA, C.R.; SILVA, S.; HAKAMADA, R.E.; FERREIRA, J.M. de A.; LIMA, A.M.N.; GAVA, J.L.; LEITE, F.P.; ANDRADE, H.B.; ALVES, J.M.; SILVA, G.G.C.; AZEVEDO, M.R. The Brazil Eucalyptus Potential Productivity Project: influence of water, nutrients and stand uniformity on wood production. Forest Ecology and Management, v.259, p.1686-1694, 2010. DOI: https://doi.org/10.1016/j.foreco.2010.01.012.

TIMOFEICZYK JUNIOR, R.; BOUCHARDET, D. de A.; FOLMANN, W.T.; HOEFLICH, V.A.; FERNANDEZ, M.L.Q. Simulação econômica de Monte Carlo aplicada à análise de risco florestal. Revista Espacios, v.38, p.5, 2017.

VIRGENS, A.P. das; FREITAS, L.C. de; LEITE, A.M.P. Análise econômica e de sensibilidade em um povoamento implantado no sudoeste da Bahia. Floresta e Ambiente, v.23, p.211-219, 2016. DOI: https://doi.org/10.1590/2179-8087.104914.

VITALE, V.; MIRANDA, G. de M. Análise comparativa da viabilidade econômica de plantios de Pinus taeda e Eucalyptus dunnii na região Centro-Sul do Paraná. Floresta, v.40, p.469-476, 2010. DOI: https://doi.org/10.5380/rf.v40i3.18908.

WEIMANN, C.; FARIAS, J.A. de; DEPONTI, G. Viabilidade econômica do componente arbóreo de sistema agrossilvipastoril comparado ao de plantio florestal na pequena propriedade rural. Pesquisa Florestal Brasileira, v.37, p.429-436, 2017. DOI: https://doi.org/10.4336/2017.pfb.37.92.1147. 